M. J. Watt · A. L. Carey • E. Wolsk-Petersen •

F. B. Kraemer · B. Klarland Pedersen • M. A. Febbraio

\title{
Hormone-sensitive lipase is reduced in the adipose tissue of patients with type 2 diabetes mellitus: influence of IL-6 infusion
}

Received: 5 April 2004 / Accepted: 31 July 2004 / Published online: 18 December 2004

(C) Springer-Verlag 2004

\begin{abstract}
Aims/hypothesis: Type 2 diabetes mellitus is characterised by increased plasma NEFA and IL-6 concentrations, and IL-6 increases lipolysis in healthy men. We assessed the adipose tissue hormone-sensitive lipase (HSL) mRNA expression, protein expression and HSL activity in patients with type 2 diabetes mellitus, and determined the effect of IL-6 administration on these measures. Methods: Seven patients with type 2 diabetes mellitus (age $67 \pm 4$ years, weight $87 \pm 7 \mathrm{~kg}$ ) and six age- and weight-matched individuals visited the laboratory on two occasions. Subcutaneous adipose tissue biopsies and blood samples were obtained prior to and during $3 \mathrm{~h}$ of either saline or recombinant human IL-6 infusion. Results: $H S L$ mRNA was reduced $(p<0.05)$ by $\sim 40 \%$ in type 2 diabetes mellitus relative to control subjects, while HSL protein expression showed a tendency to be decreased $(35 \%$, $p=0.09$ ). HSL activity averaged $8.87 \pm 1.25$ and $6.91 \pm 1.20$ nmol $\mathrm{min}^{-1} \mathrm{mg}^{-1}$ protein for control and type 2 diabetic
\end{abstract}

M. J. Watt $(\bowtie) \cdot$ A. L. Carey · M. A. Febbraio

School of Medical Sciences, RMIT University,

PO Box 71 Bundoora, 3083, Australia

e-mail: matthew.watt@rmit.edu.au

Tel.: +61-3-99257001

Fax: +61-3-99257083

E. Wolsk-Petersen - B. K. Pedersen

Department of Infectious Diseases, The University of Copenhagen,

2100 Copenhagen Ø, Denmark

B. K. Pedersen

The Copenhagen Muscle Research Centre, The University of Copenhagen,

2100 Copenhagen Ø, Denmark

F. B. Kraemer

Division of Endocrinology, Department of Medicine, Stanford University,

Stanford, CA, 94305, USA

F. B. Kraemer

Veteran Affairs Palo Alto Health Care System,

Palo Alto, CA, 94304, USA subjects respectively $(p<0.05)$. IL-6 administration increased $(p<0.05)$ HSL mRNA 2-fold at $60 \mathrm{~min}$ in both groups, whereas HSL protein and activity were unaffected by IL-6. Plasma insulin was elevated $(p<0.05)$ in patients with type 2 diabetes mellitus at rest and was blunted $(p<0.05)$ during IL-6 infusion in both groups. Plasma glucagon and cortisol were elevated $(p<0.05)$ by IL-6 in both groups. Conclusions/interpretation: Our data demonstrate that basal HSL is decreased in patients with type 2 diabetes mellitus, and this may be a consequence of elevated plasma insulin levels. We have also shown that IL-6 administration increases HSL gene expression, although it exerted no effect on HSL protein and activity. This disparity between mRNA, protein and enzyme activity may be a function either of the marked alterations in the hormonal milieu induced by IL- 6 administration and/or of post-transcriptional events.

Keywords Adipose tissue - Gene expression - Hormonesensitive lipase Interleukin-6 - Type 2 diabetes mellitus

Abbreviations HPLC: High-performance liquid chromatography - HSL: Hormone-sensitive lipase - RH: Recombinant human

\section{Introduction}

Type 2 diabetes mellitus is associated with increased plasma concentrations of circulating NEFA [1], which are thought to contribute to the pathogenesis of insulin resistance [2]. Plasma NEFA concentration reflects the balance between adipose tissue lipolysis and uptake (oxidation and esterification) by peripheral tissues. Hormone-sensitive lipase (HSL) is an important enzyme in the control of adipose tissue lipolysis, although studies in HSL knock-out mice implicate the presence of other triacylglycerol lipases [3]. HSL activity is acutely controlled by reversible phosphorylation, and is rapidly up-regulated by adrenergic stimulation, which increases intracellular cyclic AMP, protein 
kinase A, triacylglycerol hydrolysis and fatty acid release, whereas insulin antagonises these effects [4].

A number of studies have demonstrated an increased rate of NEFA turnover in obese and insulin-resistant individuals $[5,6]$, and the hormonal regulation of HSL has been well described in adipose tissue from healthy individuals [4]. Measurements of HSL activity and lipolysis have been conducted in adipose tissue of obese and insulin-resistant individuals, two conditions that precede the development of type 2 diabetes mellitus. Whereas in vitro studies have not demonstrated increased HSL activity and lipolytic rates in obesity [7], others have reported reduced HSL mRNA and protein and maximal lipolytic rate in subcutaneous adipocytes obtained from obese subjects [8]. Additionally, obese subjects expressing the truncated HSL variant $(80$ $\mathrm{M}_{\mathrm{r}}$ ), exhibit lower maximal HSL activity and lipolytic rates. As with obesity, data on the relationship of HSL with insulin resistance are conflicting, with reports of decreased maximal lipolytic rates [9] or unchanged HSL activity with insulin resistance [10]. The conflicting evidence may be due to the fact that insulin is elevated in states of insulin resistance and has a potent inhibitory effect on HSL activity. However, no information exists pertaining to adipose tissue $H S L$ gene and protein expression, and to HSL activity in patients with type 2 diabetes mellitus, who are characterised by chronically elevated insulin levels. Thus, our first aim was to determine whether the increased NEFA and insulin observed in patients with type 2 diabetes mellitus is associated with a perturbed resting expression and activity of $H S L$ gene and protein. We hypothesised that HSL activity would be reduced at rest in such patients due to the inhibitory effect of insulin, and that this could result in elevated HSL mRNA and protein expression.

The increased release of proinflammatory cytokines is related to the occurrence of obesity-related disorders such as insulin resistance and type 2 diabetes mellitus (review see [11]). It has been proposed that IL-6 plays a role in the increased plasma NEFA levels observed in type 2 diabetic patients, secondary to paracrine effects in adipose tissue. IL-6 is secreted by adipose tissue at rest $[12,13]$ and plasma IL-6 levels are elevated in insulin-resistant states $[14,15]$. IL-6 exerts lipolytic effects in adipocytes $[16,17]$ and recombinant human (rh) IL-6 infusion increases adipose tissue lipolysis in healthy humans $[18,19]$, resulting in increased plasma NEFA after prolonged $(>2 \mathrm{~h})$ infusion. Notably, the increased lipolysis occurs in the absence of changes in other hormones known to affect lipolysis [19]. Despite these findings, the mechanism or mechanisms underlying the stimulatory effect of IL-6 on adipose tissue lipolysis is not clear. In this context, our second aim was to determine the effect of IL-6 on HSL gene expression, protein expression and activity, and the plasma concentrations of various lipolytic hormones in patients with type 2 diabetes mellitus. We hypothesised that IL-6 infusion would increase HSL activity both in patients with type 2 diabetes mellitus, and in control subjects.

\section{Subjects and methods}

Subjects and study protocol We recruited seven men with type 2 diabetes mellitus (67 \pm 4 years; $87 \pm 7 \mathrm{~kg}$; BMI $27 \pm 2$ $\mathrm{kg} / \mathrm{m}^{-2}$ ) and six male age- and weight-matched control subjects $\left(64 \pm 3\right.$ years; $89 \pm 2 \mathrm{~kg}$; BMI $\left.28 \pm 1 \mathrm{~kg} / \mathrm{m}^{-2}\right)$. The categorisation of patients to the type 2 diabetes mellitus group was determined, according to WHO 1999 criteria, by a fasting blood glucose concentration of more than $7.0 \mathrm{mmol} / \mathrm{l}$ and a post-OGTT blood glucose concentration of more than $11.1 \mathrm{mmol} / \mathrm{l}$. None of the patients were receiving insulin treatment or taking oral hypoglycaemic agents or other medication known to alter carbohydrate metabolism. The time after diagnosis of type 2 diabetes mellitus was 4-10 years. Subjects were not physically active. Subjects provided their written consent after being informed of the possible risks and discomforts of the study. The study was approved by the Ethical Committee for Medical Research of Copenhagen and Frederiksberg and was conducted in accordance with the Declaration of Helsinki.

Subjects visited the laboratory on two occasions following an overnight fast and trials were separated by 7-14 days. Trials were blind, randomised and counterbalanced. Subjects were instructed to eat the same food on the day prior to the experiment on both occasions, and not to consume anything on the morning of each experiment, i.e. to come in a fasted condition. Upon arrival at the laboratory, subjects rested quietly on a bed and a venous cannula was introduced into an antecubital vein in one arm for blood sampling, and in the contralateral arm for saline or rh IL-6 infusion. At this time the subjects were also prepared for needle biopsy of the adipose tissue. For this, an incision was made through the skin and fascia under local anaesthetic (lidocaine, 2\% epinephrine) at a site $10 \mathrm{~cm}$ lateral to the navel. A venous blood sample was obtained and was immediately followed by an adipose tissue needle biopsy. A 6-mm Bergstrom needle was introduced and inserted $\sim 5 \mathrm{~cm}$ medially from the abdominal adipose incision and suction was applied during cutting. Sample sizes were $\sim 130 \mathrm{mg}$ wet mass. Adipose tissue and venous blood samples were also obtained at 1 and $3 \mathrm{~h}$ of infusion and were rapidly frozen in liquid nitrogen for later analysis.

On one occasion subjects were infused with rh IL-6, and on the other occasion with isotonic saline, both of which were mixed in sterile human albumin. IL-6 was infused at a rate of $7 \mu \mathrm{g} \mathrm{h}^{-1}$ because this dose of rh IL-6 infusion increases plasma IL-6 concentration with limited impact on the hormonal milieu [19]. No adverse systemic responses to the rh IL-6 infusion, e.g. shivering, change in core temperature, were reported by any of the subjects.

Assay of HSL activity by measuring the release of $\left[{ }^{3} \mathrm{H}\right]-$ fatty acid Adipose tissue was analysed for HSL activity as described [20] and modified [21]. An aliquot of adipose tissue $(\sim 30 \mathrm{mg})$ was homogenised for $10 \mathrm{~s}$ on ice in 20 volumes of homogenising buffer using a homogeniser (Polytron; Brinkman Instruments, Westbury, NY, USA) at full speed. After centrifugation $\left(16,000 \mathrm{~g}\right.$ for $1 \mathrm{~h}$ at $\left.4^{\circ} \mathrm{C}\right)$, 
$\mathbf{a}$

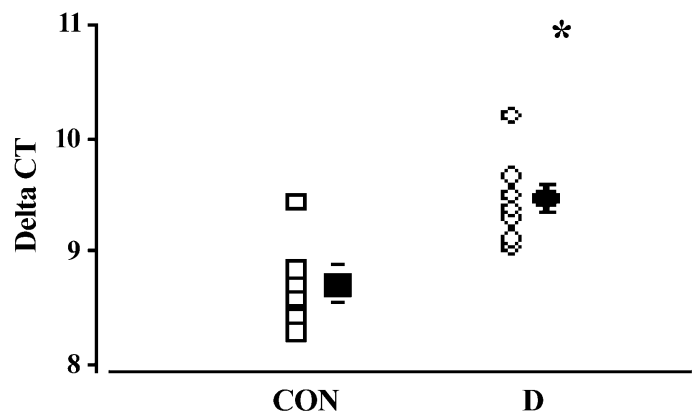

b

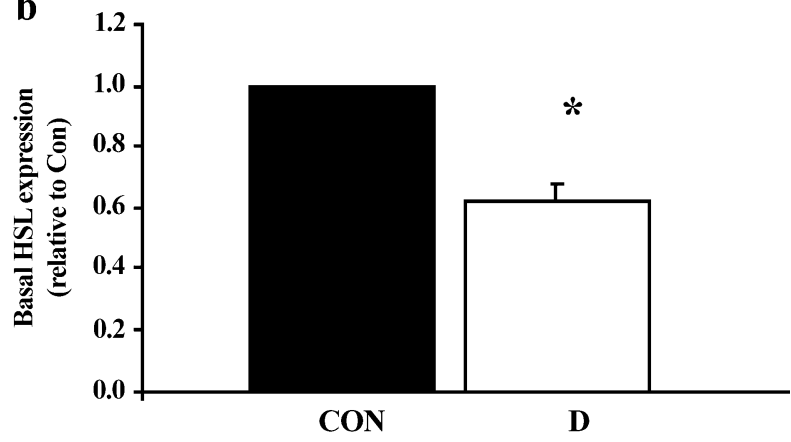

Fig. 1 HSL mRNA in type 2 diabetic patients (D) and age-matched control individuals (CON) at rest. a ${ }^{2-}{ }^{\delta \delta} \mathrm{C}_{\mathrm{T}}$ (critical threshold) values for all subjects (open symbols) and group means \pm SEM (closed symbols). A decrease of 1 in the delta $\mathrm{C}_{\mathrm{T}}$ denotes a halving of the copy number. b HSL mRNA expressed as fold change relative to the control sample. Values are means \pm SEM, $n=6-7 .{ }^{*} p<0.05$ for difference in main effect from $\mathrm{CON}$

the fat-depleted infranatant was removed and stored on ice for immediate analysis of HSL activity. A substrate consisting of $5 \mathrm{mmol} / 1$ triolein, $14 \times 10^{6} \mathrm{dpm}[9,10]$ triolein, $0.6 \mathrm{mg}$ phospholipid (phosphatidylcholine/phosphatidylinositol $3: 1 \mathrm{w} / \mathrm{w}$ ), $0.1 \mathrm{~mol} / 1$ potassium phosphate and $20 \%$ BSA was emulsified by sonication. The adipose homog-

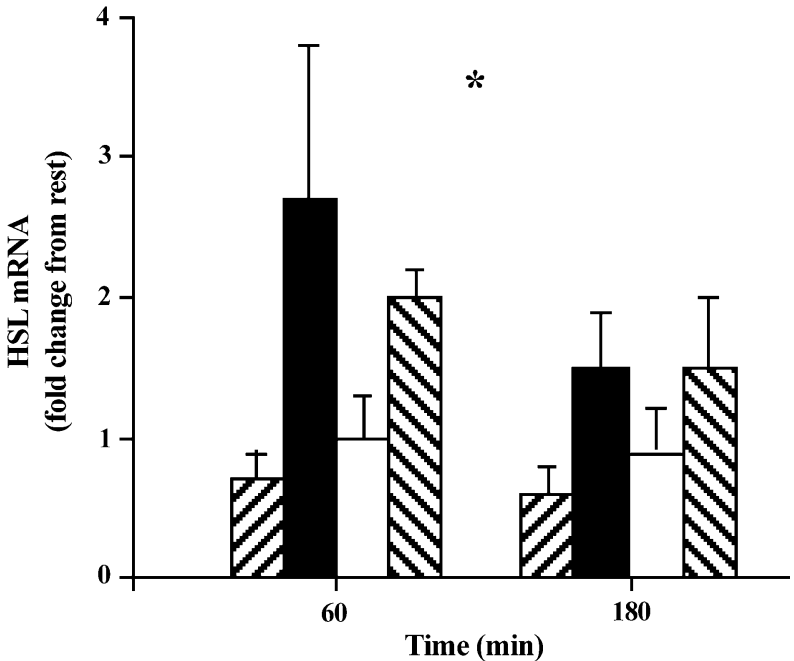

Fig. 2 HSL mRNA in type 2 diabetic patients and age-matched control individuals during $180 \mathrm{~min}$ rh IL-6 or saline infusion. Data are expressed as fold change relative to the control sample. Values are means \pm SEM, $n=6-7$. ${ }^{*} p<0.05$ for difference in main effect from CON. Hatched bars (stripes rising left to right) Control (CON) saline, filled bars CON Il-6, open bars diabetic (D) saline, hatched bars (descending left to right) diabetic Il-6

enate supernatant $(15 \mu \mathrm{l})$ was incubated at $37^{\circ} \mathrm{C}$ with enzyme dilution buffer $(85 \mu \mathrm{l})$ and $100 \mu \mathrm{l}$ of triolein substrate. The reaction was stopped after $20 \mathrm{~min}$ by the addition of $3.25 \mathrm{ml}$ of a methanol/chloroform/heptane (10:9:7, v:v:v) solution, and $1.1 \mathrm{ml}$ of $0.1 \mathrm{~mol} / 1$ potassium carbonate or $0.1 \mathrm{~mol} / \mathrm{l}$ boric acid were added to facilitate the separation of the organic and aqueous phases. The mixture was mixed on a vortex, spun in a centrifuge at $1,100 \mathrm{~g}$ for $20 \mathrm{~min}$ and $1 \mathrm{ml}$ of the upper phase containing the released fatty acids was removed for determination of radioactivity on a beta spectrometer (Tri-Carb 1500;

Table 1 Plasma IL-6 and hormone responses during $180 \mathrm{~min}$ of saline or rh IL-6 infusion in type 2 diabetic patients (D) and age-matched control subjects $(\mathrm{CON})$

\begin{tabular}{|c|c|c|c|c|c|c|c|}
\hline & & \multicolumn{2}{|l|}{$0 \mathrm{~min}$} & \multicolumn{2}{|l|}{$60 \mathrm{~min}$} & \multicolumn{2}{|l|}{$180 \mathrm{~min}$} \\
\hline & & Saline & IL-6 & Saline & IL-6 & Saline & IL-6 \\
\hline \multirow[t]{2}{*}{ IL-6 (pg/ml) } & $\mathrm{D}$ & $4.3 \pm 0.7$ & $7.5 \pm 2.1$ & $5.8 \pm 1.0$ & $181 \pm 35^{* \#}$ & $6.6 \pm 0.9$ & $204 \pm 31{ }^{* \#}$ \\
\hline & $\mathrm{CON}$ & $2.8 \pm 0.2$ & $5.1 \pm 1.5$ & $4.5 \pm 0.8$ & $199 \pm 7.1{ }^{* \#}$ & $5.2 \pm 0.4$ & $220 \pm 60 * \#$ \\
\hline \multirow[t]{2}{*}{ Insulin (pmol/1) } & $\mathrm{D}^{\dagger}$ & $92 \pm 28$ & $81 \pm 31$ & $65 \pm 19$ & $72 \pm 23$ & $53 \pm 15$ & $43 \pm 16^{*}$ \\
\hline & $\mathrm{CON}$ & $37 \pm 11$ & $37 \pm 8$ & $38 \pm 11$ & $31 \pm 11$ & $27 \pm 7$ & $21 \pm 6^{*}$ \\
\hline \multirow[t]{2}{*}{ Epinephrine (nmol/1) } & $\mathrm{D}$ & $0.54 \pm 0.11$ & $0.36 \pm 0.10$ & $0.46 \pm 0.03$ & $0.23 \pm 0.06$ & $0.46 \pm 0.08$ & $0.21 \pm 0.03$ \\
\hline & $\mathrm{CON}$ & $0.37 \pm 0.14$ & $0.47 \pm 0.22$ & $0.17 \pm 0.04$ & $0.53 \pm 0.18$ & $0.27 \pm 0.15$ & $0.26 \pm 0.10$ \\
\hline \multirow[t]{2}{*}{ Norepinephrine (nmol/1) } & $\mathrm{D}$ & $1.21 \pm 0.21$ & $1.00 \pm 0.10$ & $0.99 \pm 0.27$ & $1.77 \pm 0.30$ & $0.82 \pm 0.14$ & $1.27 \pm 0.21$ \\
\hline & $\mathrm{CON}$ & $1.68 \pm 0.62$ & $1.22 \pm 0.35$ & $1.34 \pm 0.39$ & $1.97 \pm 0.59$ & $1.33 \pm 0.32$ & $1.29 \pm 0.22$ \\
\hline \multirow[t]{2}{*}{ Glucagon (pg/ml) } & $\mathrm{D}$ & $71 \pm 9$ & $75 \pm 8$ & $72 \pm 8$ & $80 \pm 7 *$ & $66 \pm 7$ & $88 \pm 7 *$ \\
\hline & $\mathrm{CON}$ & $74 \pm 9$ & $76 \pm 11$ & $71 \pm 10$ & $85 \pm 16^{*}$ & $75 \pm 12$ & $86 \pm 12 *$ \\
\hline \multirow[t]{2}{*}{ Cortisol (pg/ml) } & $\mathrm{D}$ & $10.2 \pm 1.8$ & $6.6 \pm 1.0$ & $7.7 \pm 1.6$ & $16.0 \pm 1.3 *$ & $8.1 \pm 0.9$ & $16.0 \pm 0.7 *$ \\
\hline & $\mathrm{CON}$ & $8.1 \pm 1.0$ & $8.1 \pm 1.9$ & $5.7 \pm 0.6$ & $18.1 \pm 1.6^{*}$ & $5.6 \pm 0.9$ & $18.7 \pm 3.0^{*}$ \\
\hline
\end{tabular}

Data are presented as means \pm SEM, $n=6-7$

$* p<0.05$ for difference from $0 \mathrm{~h}$ of the same trial ${ }^{\dagger} p<0.05$ for difference of group effect CON vs D ${ }^{\#} p<0.05$ for difference from saline 
Packard, Canberra, Australia). Activity was normalised to the total protein content of the homogenate (Pierce, Rockford, IL, USA). Because a triacylglycerol substrate was used, this assay measured HSL activity in the active form (net phosphorylation) and not maximal activity.

Determination of HSL protein by western blot analysis Adipose tissue ( $40 \mathrm{mg}$ ) was homogenised (Brinkman Instruments) in ice-cold buffer containing $50 \mathrm{mmol} / \mathrm{l}$ HEPES, $150 \mathrm{mmol} / 1 \mathrm{NaCl}, 10 \mathrm{mmol} / \mathrm{l} \mathrm{NaF}, 1 \mathrm{mmol} / 1$ $\mathrm{Na}_{3} \mathrm{VO}_{4}, 5 \mathrm{mmol} / \mathrm{l}$ EDTA, $0.5 \%$ Triton X-100, 10\% glycerol (v:v), $2 \mu \mathrm{g} / \mathrm{ml}$ leupeptin, $100 \mu \mathrm{g} / \mathrm{ml}$ phenylmethylsulfonyl fluoride, and $2 \mu \mathrm{g} / \mathrm{ml}$ aprotinin. Homogenates were centrifuged at $16,000 \mathrm{~g}$ for $60 \mathrm{~min}$ and the infranatant was removed and rapidly frozen in liquid nitrogen. Protein concentration of the tissue lysates was subsequently determined (Pierce). Tissue lysates $(120 \mu \mathrm{g})$ were solubilised in Laemmli sample buffer and boiled for 5 min, resolved by SDS-PAGE on $10 \%$ polyacrylamide gels, transferred to a nitrocellulose membrane, blocked with 5\% non-fat dry milk and immunoblotted with a polyclonal anti-rat HSL antibody $(1: 2,000)$. This antibody recognises human HSL with lower affinity than rat HSL. After incubation with horseradish peroxidase-conjugated secondary antibody (1:2,000; Amersham Biosciences, Castle Hill, NSW, Australia), the immunoreactive proteins were detected with enhanced chemiluminescence (Perkin Elmer, Rowville, Victoria, Australia) and quantified by densitometry, followed by analysis using Kodak 1D image analysis software. To compare HSL density between blots, an internal standard consisting of an aliquot of homogenised rat adipose tissue was included in each gel.

Determination of HSL mRNA by RT-PCR Approximately $60 \mathrm{mg}$ of adipose was extracted for total RNA using a modification of the acid guanidium thiocyanate-phenol

$\mathbf{a}$

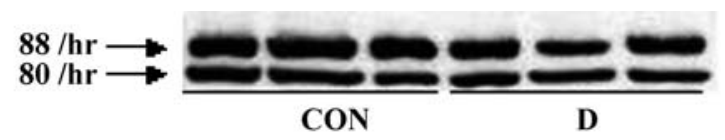

b

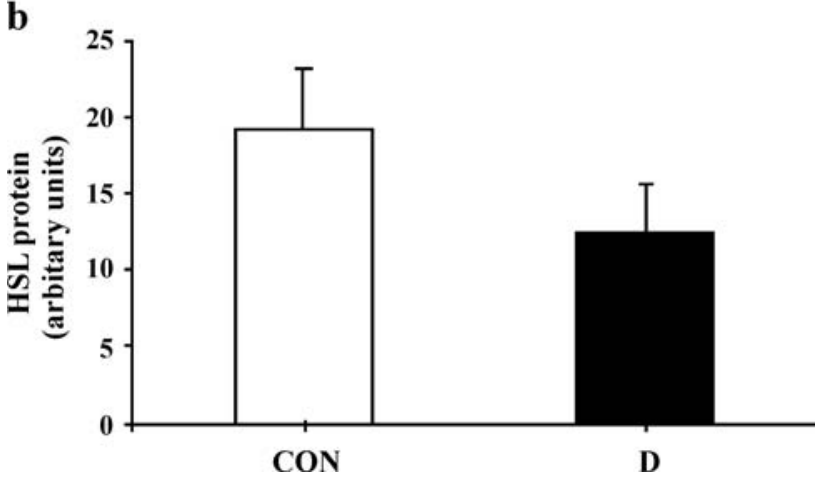

Fig. 3 HSL protein expression in type 2 diabetic patients and agematched control individuals at rest. a A representative immunoblot of HSL from adipose tissue. b Abundance of hormone-sensitive lipase in adipose tissue from type 2 diabetic patients (D) and agematched control individuals (CON). Densitometry from both bands is reported. Values are means $\pm \mathrm{SEM}, n=6-7$ chloroform extraction method described elsewhere [22]. The total RNA was quantified and 1 ng of each total RNA sample was reverse-transcribed in a $10-\mathrm{ml}$ reaction previously described [22]. Control samples were also analysed where all the above reagents are added to RNA samples except the Multiscribe Reverse Transcriptase. The reverse transcription reactions were performed using a GeneAmp PCR system 2400 (Perkin Elmer, Wellesley, MA, USA) with conditions at $25^{\circ} \mathrm{C}$ for $10 \mathrm{~min}, 48^{\circ} \mathrm{C}$ for $30 \mathrm{~min}$ and $95^{\circ} \mathrm{C}$ for $5 \mathrm{~min}$. We added $2 \mathrm{ml} 0.5 \mathrm{mmol} / 1$ EDTA (pH 8.0) to each sample and stored them at $-20^{\circ} \mathrm{C}$ until further analysis. Real-time PCR was employed to quantitate human
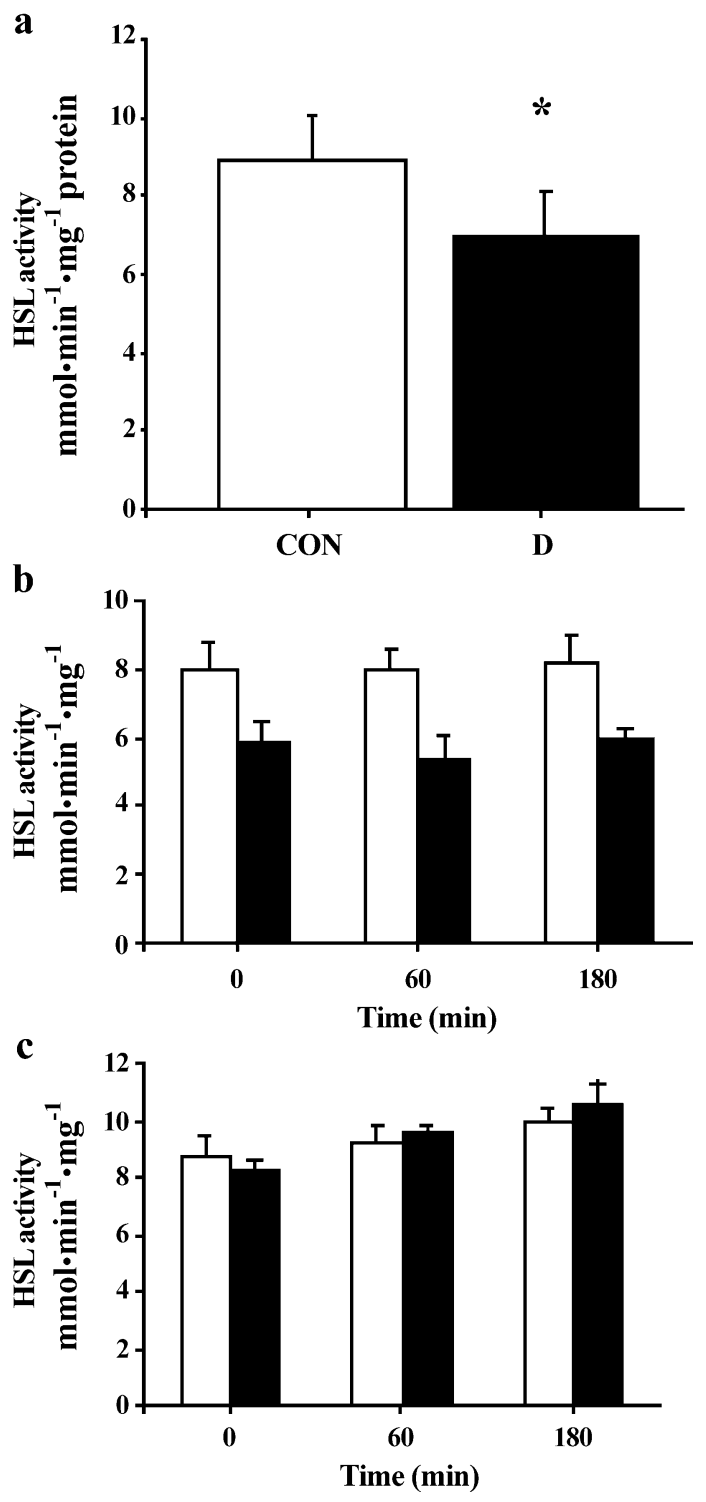

Fig. 4 HSL activity in type 2 diabetic patients (D) and age-matched control individuals (CON) at rest. a Results during 180-min rh IL-6 (filled bar) or saline infusion (open bar) in type 2 diabetic patients. b Results for same infusions and subjects at three time points. c Results for same infusions and time points in age-matched control subjects (filled bars rh IL-6, open bars saline). HSL activity was measured against a triolein substrate, which represents in vivo activity and not maximal activity. Values are means \pm SEM, $n=6-7$. ${ }^{*} p<0.05$ for difference in main effect from CON 
HSL mRNA. Human probe and primers were designed (Primer Express version 1.0 Applied Biosystems) from the human gene sequence accessed from Gen-Bank/EMBL. A 63-bp gene fragment was amplified using the forward primer 5'-ACGCTGCATAAGGGATGCTT-3', the reverse primer 5'-CCTGTCTCGTTGCGTTTGTAGT-3' (Sigma Geno-sys, Castle Hill, NSW, Australia) and a Taqman fluorescent probe 5'-FAM-CCTGTCTCGTTGCGTTTGTAGT-3' TAMRA (Applied Biosystems, Foster City, CA, USA). Ribosomal $18 \mathrm{~S}$ was used as a constitutive housekeeping control (Applied Biosystems). We quantitated gene expression using a multiplex comparative critical threshold method (iCycler IQTM; Bio-Rad, Hercules, CA, USA) described in detail elsewhere [23]. Our real-time PCR methodology has been previously validated against other methods of mRNA measurements [24].

Plasma hormone and metabolite analysis Plasma IL-6 was measured by a high-sensitivity enzyme-linked immunosorbent assay (R\&D Systems, Minneapolis, MN, USA). Plasma insulin (Amersham Pharmacia Biotech, Uppsala, Sweden), cortisol (Diagnostic Products, Los Angeles, CA, USA) and glucagon (Linco Research, St. Charles, IL, USA) were measured by radioimmunoassay, and plasma catecholamines by HPLC as previously described [25]. Plasma NEFA and glycerol were measured using an automated analyser (Cobas Fara, Roche, France).

Statistics All data are expressed as means \pm SEM. Statistical significance was assessed by a three-way analysis of variance with repeated measures (group-condition-time). Specific differences were located using a StudentNewman-Keuls post hoc test. Statistical significance was set at a $p$ value of less than 0.05 .

\section{Results}

Plasma IL-6 Plasma IL-6 did not differ $(p=0.24)$ at rest between the two groups, averaging $3.84 \pm 0.32 \mathrm{pg} / \mathrm{ml}$. IL-6 infusion resulted in marked increases $(p<0.05)$ in plasma IL-6 in control and type 2 diabetic subjects (Fig. 1). Saline infusion had no effect on plasma IL-6 (Table 1).
HSL mRNA The lower $(p<0.05)$ basal expression of HSL mRNA in type 2 diabetic patients relative to control subjects was consistent across all subjects (Fig. 1a). When expressed relative to control, $H S L$ mRNA was $\sim 40 \%$ lower $(p<0.05)$ in subjects with type 2 diabetes mellitus (Fig. 1b). At 60 min IL-6 increased ( $p<0.05$, time-treatment interaction) HSL mRNA expression $~ 2.5$-fold in both groups, but there were no differences in the response to IL-6 when comparing groups (Fig. 2). There was no significant difference between pre-infusion and 180-min HSL mRNA in the two groups.

HSL protein HSL protein expression at 0 min was not different ( $p=0.09$ ) between groups (Fig. 3 ) and was unaffected by IL-6 infusion (data not shown). HSL expression between subjects was variable and ranged between 5 and 35 arbitary units. The $88-\mathrm{M}_{\mathrm{r}}$ HSL band represented $58 \pm 3 \%$ of the total HSL density in control subjects, whereas the $80-\mathrm{M}_{\mathrm{r}}$ HSL band represented $42 \pm 3 \% \quad(p<0.05)$. The proportion of $88-\mathrm{M}_{\mathrm{r}}(56 \pm 4 \%)$ and $80-\mathrm{M}_{\mathrm{r}}(44 \pm 3 \%)$ bands to total HSL was similar between groups.

HSL activity Resting HSL activity in control subjects averaged $8.87 \pm 1.25 \mathrm{nmol} \mathrm{min} \mathrm{mg}^{-1}$ protein, and was attenuated $(p<0.05)$ in subjects with type 2 diabetes mellitus $\left(6.91 \pm 1.20 \mathrm{nmol} \mathrm{min}{ }^{-1} \mathrm{mg}^{-1}\right.$ protein) (Fig. 4a). When these data were expressed relative to adipose tissue mass, which takes into account potential changes in fat content within the adipocytes, these differences between control and type 2 diabetic subjects persisted. HSL activity was not affected by IL-6 or saline infusion in either group (Fig. 4b,c). There was no correlation between HSL protein (total, $\left.88 \mathrm{M}_{\mathrm{r}}, 80 \mathrm{M}_{\mathrm{r}}\right)$ and HSL activity $\left(r^{2}=0.02\right)$.

Plasma hormones Plasma insulin was higher $(p<0.05)$ in type 2 diabetic than in control subjects (Table 1). Plasma insulin progressively decreased $(p<0.05)$ during IL-6 infusion, such that at $180 \mathrm{~min}$ insulin during IL-6 infusion was lower $(p<0.05$; time-treatment interaction). Plasma insulin during saline infusion was not different from that during rest in either group. With regard to plasma epinephrine and norepinephrine, there was no difference between groups or trials, and values were unaffected by

Table 2 Plasma NEFA and glucose concentrations during 180 min of saline or rh IL-6 infusion in type 2 diabetic patients (D) and agematched control subjects $(\mathrm{CON})$

\begin{tabular}{|c|c|c|c|c|c|c|c|}
\hline & & \multicolumn{2}{|l|}{$0 \mathrm{~min}$} & \multicolumn{2}{|l|}{$60 \mathrm{~min}$} & \multicolumn{2}{|l|}{$180 \mathrm{~min}$} \\
\hline & & Saline & IL-6 & Saline & IL-6 & Saline & IL-6 \\
\hline \multirow[t]{2}{*}{ NEFA $(\mathrm{mmol} / \mathrm{l})$} & $\mathrm{D}$ & $0.91 \pm 0.16^{\dagger}$ & $0.91 \pm 0.16^{\dagger}$ & $0.89 \pm 0.13^{\dagger}$ & $0.87 \pm 0.19$ & $0.84 \pm 0.225$ & $1.12 \pm 0.23^{*}$ \\
\hline & $\mathrm{CON}$ & $0.81 \pm 0.05$ & $0.83 \pm 0.12$ & $0.69 \pm 0.04$ & $0.85 \pm 0.14$ & $0.70 \pm 0.0$ & $1.09 \pm 0.10^{*}$ \\
\hline \multirow[t]{2}{*}{ Glycerol $(\mu \mathrm{mol} / \mathrm{l})$} & $\mathrm{D}$ & $100 \pm 12$ & $115 \pm 12$ & $97 \pm 8$ & $99 \pm 11$ & $93 \pm 11$ & $114 \pm 7$ \\
\hline & $\mathrm{CON}$ & $88 \pm 24$ & $89 \pm 19$ & $74 \pm 9$ & $95 \pm 12$ & $99 \pm 17$ & $125 \pm 16$ \\
\hline \multirow[t]{2}{*}{ Glucose (mmol/l) } & $\mathrm{D}$ & $8.14 \pm 0.51^{\dagger}$ & $8.12 \pm 0.53^{\dagger}$ & $7.98 \pm 0.34^{\dagger}$ & $7.77 \pm 0.47^{\dagger}$ & $7.60 \pm 0.32^{\dagger}$ & $7.51 \pm 0.26^{\dagger}$ \\
\hline & $\mathrm{CON}$ & $5.53 \pm 0.25$ & $5.48 \pm 0.19$ & $5.41 \pm 0.35$ & $5.19 \pm 0.20$ & $5.01 \pm 0.16$ & $5.39 \pm 0.18$ \\
\hline
\end{tabular}

Data are presented as means \pm SEM, $n=6-7$

$* p<0.05$ for difference from $0 \mathrm{~h}$ of the same trial

$p<0.05$ for difference from corresponding time point for CON 
time (Table 1). Plasma glucagon was not different between groups and was increased $(p<0.05)$ at 60 and $180 \mathrm{~min}$ during IL-6 infusion in both groups (Table 1). Plasma cortisol was increased by 60 min during IL- 6 infusion in both groups and remained elevated at $180 \mathrm{~min}$ (Table 1). Saline infusion had no effect on plasma cortisol.

Plasma metabolites Plasma NEFA concentrations were higher $(p<0.05)$ at rest in type 2 diabetic subjects compared with control subjects (Table 2). Plasma NEFA was unaffected during saline infusion in both trials; whereas IL-6 infusion elicited a 23\% (type 2 diabetes mellitus) and $31 \%$ (control) increase $(p<0.05)$ in plasma NEFA by 180 min. Plasma glycerol was not different between groups or between trials (Table 2). Plasma glucose was higher $(p<0.05)$ in type 2 diabetic subjects, but was unaffected in either group by saline or IL-6 infusions (Table 2).

\section{Discussion}

The present study demonstrates that patients with type 2 diabetes mellitus have decreased adipose tissue $H S L$ mRNA and activity, with a tendency $(p=0.09)$ for HSL protein to also be lower. Furthermore, acute rh IL-6 administration increases $H S L$ expression but is without effect on HSL protein and activity in type 2 diabetic and control subjects. However, changes in the hormonal milieu do not allow the effects of IL- 6 on HSL activity to be directly determined.

Fatty acids derived from adipose tissue triacylglycerol hydrolysis are thought to contribute to the pathogenesis of insulin resistance and type 2 diabetes mellitus [26]. Plasma NEFA concentrations are elevated in type 2 diabetes mellitus. However, the underlying mechanisms leading to the pathogenesis are unresolved, although HSL is thought to play an important role because it catalyses hydrolysis of triacylglycerols and diacylglycerols via its interaction with perilipins and the lipid droplet [4]. In this context, we examined the activity of HSL in patients with type 2 diabetes mellitus and age- and weight-matched normoglycaemic/normoinsulinaemic control subjects.

The reduction in HSL mRNA $(\sim 40 \%)$, protein $(35 \%$, NS) and HSL activity (25\%) observed in patients with type 2 diabetes mellitus did not entirely support our original hypothesis. We hypothesised that HSL activity would be lower in patients with type 2 diabetes mellitus even though they had elevated plasma NEFA, because of the inhibitory effect of insulin, which was markedly higher in this group. While our data are consistent with this hypothesis, we also predicted that this would result in an upregulation of the mRNA expression and protein, as more protein would need to be translated due to the lower activity. However, mRNA and protein expression were attenuated in subjects with type 2 diabetes mellitus, suggesting that HSL phosphorylation is important in mediating the decreased HSL activity.

Alternatively, the greater lipolysis previously observed in type 2 diabetic patients [24] may result from other control points of lipolysis such as increased translocation of HSL to its substrate $[27,28]$ and/or alterations in perilipin phosphorylation [29]. Decreased perilipin expression is associated with increased maximal stimulated lipolysis [30], but whether perilipin expression is attenuated in individuals with type 2 diabetes mellitus is unknown. The increased plasma NEFA levels observed in type 2 diabetes mellitus may not be a function of increased lipolysis but may instead be a function of decreased skeletal muscle fatty acid transport [31, 32] and/or reduced oxidative capacity $[33,34]$. If this were indeed the case, then it is possible that the decreases in HSL mRNA, protein and activity are due to a feedback mechanism, whereby the rate-limiting enzyme in lipolysis is down-regulated to limit the systemic concentration of NEFA and the degree of pathogenesis associated with hyperlipidaemia. Such a hypothesis warrants further investigation.

A significant finding of the present study was the high expression of both immunoreactive HSL bands ( 80 and $88 \mathrm{M}_{\mathrm{r}}$ ). An alternatively spliced form of human HSL (HSL-s, $80 \mathrm{M}_{\mathrm{r}}$ ), which results from the in-frame skipping of exon-6, was recently identified [35]. HSL-s is devoid of lipolytic activity and HSL-s is expressed in individuals with reduced HSL activity and maximal lipolytic capacity $[8,36]$. In the present study, HSL-s was detected in all subjects and represented $\sim 40 \%$ of the total HSL protein, which is consistent with the ratio of the lower immunoreactive band previously detected in subjects with "low" maximal lipolytic rates [8], and parallels the reduced HSL mRNA in subjects with type 2 diabetes mellitus. In contrast, HSL-s represents only $\sim 15 \%$ of total HSL protein [8] or is not detected [36] in subjects with "high" lipolytic rates. It has yet to be ascertained whether the relatively large portion of HSL-s affects resting lipolysis in vivo, which is a more relevant measure than maximally stimulated lipolysis in vitro. In this regard, plasma glycerol (Table 2) was not different between trials, and preliminary experiments from our laboratory suggest that the rate of appearance of palmitate is not related to HSL activity at rest $\left(r^{2}=0.12, n=8\right)$. It is also well documented that total HSL protein is positively correlated with maximal HSL activity and maximal lipolysis [8]. We determined the relationship between HSL protein (total, 88- $\mathrm{M}_{\mathrm{r}}$ HSL and $80-\mathrm{M}_{\mathrm{r}}$ HSL) and resting HSL activity and report no meaningful correlations. These data suggest that "nonmaximal" HSL activity is largely determined by phosphorylation of the serine sites and not total protein content or the amount of HSL-s expressed.

Infusion of rh IL-6 into healthy humans increases net NEFA release from adipose tissue and increases wholebody lipolysis independently of marked changes in the hormonal milieu [19]. Therefore, we hypothesised that IL-6 would increase HSL activity. IL-6 increased plasma NEFA in both groups (Table 2) and as a consequence we were not surprised to find that in all subjects IL-6 increased $H S L$ mRNA expression after $60 \mathrm{~min}$. Interestingly, even though infusion persisted for $180 \mathrm{~min}, H S L$ mRNA returned to basal levels by this time. Despite the increased $H S L$ mRNA, protein levels were unaffected by 
IL-6, which suggests that post-transcriptional events preclude the expected increase in HSL protein or that the HSL protein turnover rate is relatively slow. Given the mRNA data and the increased plasma NEFA seen during IL-6 infusion, the absence of change in HSL protein and activity in response to IL-6 was surprising. However, concomitant decreases in plasma insulin and increased plasma glucagon and cortisol confounded the possible effect or effects of IL-6 on HSL activity in type 2 diabetic patients. The reduced insulin would be expected to remove the inhibition on lipolysis [37], whereas cortisol $[38,39]$ and glucagon [40] may increase lipolysis. Thus, it is possible that any direct stimulatory effect of IL-6 could be masked by the altered hormonal milieu induced by IL- 6 infusion. Additionally, there are many components to the lipolytic response, of which HSL activation is only one. IL-6 may be involved in the translocation of HSL to the lipid droplet and/or the phosphorylation of proteins, such as perilipins, embedded on the lipid droplet surface, and this may explain the mechanism of lipolysis induced by IL-6 [41, 42]. Alternatively, $H S L^{-/}$mice accumulate diacylglycerol in adipose tissue, suggesting the presence of another triacylglycerol lipase [3]. Irrespective of the exact mechanism, it is difficult to explain the apparent mismatch between HSL activity, the increased plasma NEFA and the previously measured increase in adipose tissue lipolysis during IL-6 infusion $[18,19]$. Finally, it is possible that we may have missed an effect on HSL activity at the selected time points. However, the consistent hormonal milieu within each trial would argue against such a possibility and further support the likelihood that another non-HSL-dependent mechanism is responsible for IL-6-induced lipolysis.

In conclusion, we have demonstrated for the first time that HSL mRNA, protein and activity are decreased in adipose tissue of patients with type 2 diabetes mellitus and that IL-6 increases HSL mRNA but not HSL activity. These data enhance our understanding of the processes of lipolysis in the pathogenesis of type 2 diabetes mellitus.

Acknowledgements This work was supported by the Danish National Research Foundation (Grant 504-14), the Danish Medical Research Council (Grant 22-01-009) and the National Health and Medical Research Council of Australia (Grant 251558). M.J. Watt is supported by a Peter Doherty postdoctoral fellowship and M.A. Febbraio by a senior research fellowship from the National Health and Medical Research Council of Australia. The authors acknowledge the excellent technical assistance of Carsten Nielsen, Ruth Rousing, Hanne Willumsen, Kristina Møller and Karin Juel.

\section{References}

1. Baldeweg SE, Golay A, Natali A, Balkau B, Del Prato S, Coppack SW (2000) Insulin resistance, lipid and fatty acid concentrations in 867 healthy Europeans. European Group for the Study of Insulin Resistance (EGIR). Eur J Clin Invest 30:45-52

2. Boden G (1997) Role of fatty acids in the pathogenesis of insulin resistance and NIDDM. Diabetes 46:3-10
3. Haemmerle G, Zimmermann R, Hayn M et al (2002) Hormonesensitive lipase deficiency in mice causes diglyceride accumulation in adipose tissue, muscle, and testis. J Biol Chem 277:4806-4815

4. Holm C, Osterlund T, Laurell H, Contreras JA (2000) Molecular mechanisms regulating hormone-sensitive lipase and lipolysis. Annu Rev Nutr J 20:365-393

5. Bolinder J, Kerckhoffs DA, Moberg E, Hagstrom-Toft E, Arner P (2000) Rates of skeletal muscle and adipose tissue glycerol release in nonobese and obese subjects. Diabetes 49:797-802

6. Horowitz JF, Coppack SW, Paramore D, Cryer PE, Zhao G, Klein S (1999) Effect of short-term fasting on lipid kinetics in lean and obese women. Am J Physiol 276:E278-E284

7. Arner P, Bolinder J, Engfeldt P, Ostman J (1981) The antilipolytic effect of insulin in human adipose tissue in obesity, diabetes mellitus, hyperinsulinemia, and starvation. Metabolism 30:753-760

8. Large V, Reynisdottir S, Langin D, Fredby K, Klannemark M, Holm C, Arner P (1998) Decreased expression and function of adipocyte hormone-sensitive lipase in subcutaneous fat cells of obese subjects. J Lipid Res 40:2059-2066

9. Reynisdottir S, Ellerfeldt K, Wahrenberg H, Lithell H, Arner P (1994) Multiple lipolysis defects in the insulin resistance (metabolic) syndrome. J Clin Invest 93:2590-2599

10. Reynisdottir S, Angelin B, Langin D et al (1997) Adipose tissue lipoprotein lipase and hormone-sensitive lipase. Contrasting findings in familial combined hyperlipidemia and insulin resistance syndrome. Arterioscler Thromb Vasc Biol 17: 2287-2292

11. Marette A (2002) Mediators of cytokine-induced insulin resistance in obesity and other inflammatory settings. Curr Opin Clin Nutr Metab Care 5:377-383

12. Mohamed-Ali V, Goodrick S, Rawesh A et al (1997) Subcutaneous adipose tissue releases interleukin-6, but not tumor necrosis factor-alpha, in vivo. J Clin Endocrinol Metab 82:4196-4200

13. Orban Z, Remaley AT, Sampson M, Trajanoski Z, Chrousos GP (1999) The differential effect of food intake and beta-adrenergic stimulation on adipose-derived hormones and cytokines in man. J Clin Endocrinol Metab 84:2126-2133

14. Kern PA, Ranganathan S, Li C, Wood L, Ranganathan G (2001) Adipose tissue tumor necrosis factor and interleukin-6 expression in human obesity and insulin resistance. Am J Physiol Endocrinol Metab 280:E745-E751

15. Bastard JP, Macchi M, Van Nhieu JT et al (2002) Adipose tissue IL-6 content correlates with insulin activation of glucose uptake both in vivo and in vitro. J Clin Endocrinol Metab 87:2084-2089

16. Mattacks CA, Pond CM (1999) Interactions of noradrenalin and tumor necrosis factor alpha, interleukin-4 and interleukin-6 in the control of lipolysis from adipocytes around lymph nodes. Cytokine 11:334-346

17. Päth G, Bornstein SR, Gurniak M, Chrousos GP, Scherbaum WA, Hauner H (2001) Human breast adipocytes express interleukin-6 (IL-6) and its receptor system: increased IL-6 production by $\beta$-adrenergic activation and effects of IL- 6 on adipocyte formation. J Clin Endocrinol Metab 86:2281-2288

18. Lynsgo D, Simonsen L, Bülow J (2002) Metabolic effects on interleukin-6 in human splanchnic and adipose tissue. J Physiol 543:379-386

19. Van Hall G, Steensberg A, Saacchetti M et al (2003) Interleukin-6 stimulates lipolysis and fat oxidation in humans. J Clin Endocrinol Metab 88:3005-3010

20. Fredrikson G, Stralfors P, Niesson NO, Belfrage P (1981) Hormone-sensitive lipase from adipose tissue of rat. Methods Enzymol 71:636-646

21. Watt MJ, Heigenhauser GJF, Spriet LL (2003) Effects of dynamic exercise intensity on activation of hormone-sensitive lipase activation in human skeletal muscle. J Physiol 547:301308 
22. Febbraio MA, Koukoulas I (1999) HSP72 gene expression progressively increases in human skeletal muscle during prolonged, exhaustive exercise. J Appl Physiol 89:1055-1060

23. Starkie RL, Arkinstall MJ, Koukoulas I, Hawley JA, Febbraio MA (2001) Carbohydrate ingestion attenuates the increase in plasma interleukin-6, but not skeletal muscle interleukin-6 mRNA, during exercise in humans. J Physiol 533:585-591

24. Steensberg A, Febbraio MA, Osada T et al (2001) Interleukin-6 production in contracting human skeletal muscle is influenced by pre-exercise muscle glycogen content. J Physiol 537:633639

25. Blomstrand E, Saltin B (1999) Effect of muscle glycogen on glucose, lactate and amino acid metabolism during exercise and recovery in human subjects. J Physiol 514:293-302

26. Lewis GF, Carpentier A, Adeli K, Giacca A (2002) Disordered fat storage and mobilization in the pathogenesis of insulin resistance and type 2 diabetes. Endocr Rev 23:201-229

27. Clifford GM, Londos C, Kraemer FB, Vernon RG, Yeaman SJ (2000) Translocation of hormone-sensitive lipase and perilipin upon lipolytic stimulation of rat adipocytes. J Biol Chem 275:5011-5015

28. Morimoto C, Kameda K, Tsujita T, Okuda H (2001) Relationships between lipolysis induced by various lipolytic agents and hormone-sensitive lipase in rat fat cells. J Lipid Res 42:120127

29. Souza SC, Muliro KV, Liscum L et al (2002) Modulation of hormone-sensitive lipase and protein kinase A-mediated lipolysis by perilipin A in an adenoviral reconstituted system. J Biol Chem 277:8267-8272

30. Mottagui-Tabar S, Ryden M, Lofgren P et al (2003) Evidence for an important role of perilipin in the regulation of human adipocyte lipolysis. Diabetologia 46:789-796

31. Kelley DE, Mokan M, Simoneau JA, Mandarino LJ (1993) Interaction between glucose and free fatty acid metabolism in human skeletal muscle. J Clin Invest 92:91-98

32. Kelley DE, Simoneau JA (1994) Impaired free fatty acid utilization by skeletal muscle in non-insulin-dependent diabetes mellitus. J Clin Invest 94:2349-2356
33. Kim JY, Hickner RC, Cortright RL, Dohm GL, Houmard JA (2000) Lipid oxidation is reduced in obese human skeletal muscle. Am J Physiol Endocrinol Metab 279:E1039-E1044

34. Simoneau JA, Veerkamp JH, Turcotte LP, Kelley DE (1999) Markers of capacity to utilize fatty acids in human skeletal muscle: relation to insulin resistance and obesity and effects of weight loss. FASEB J 13:2051-2060

35. Laurell H, Grober J, Vindis C et al (1997) Species-specific alternative splicing generates a catalytically inactive form of human hormone-sensitive lipase. Biochem J 328:137-143

36. Ray H, Beylot M, Arner P et al (2003) The presence of a catalytically inactive form of hormone-sensitive lipase is associated with decreased lipolysis in abdominal subcutaneous adipose tissue of obese subjects. Diabetes 52:1417-1422

37. Enoksson S, Degerman E, Hagstrom-Toft E, Large V, Arner P (1998) Various phosphodiesterase subtypes mediate the in vivo antilipolytic effect of insulin on adipose tissue and skeletal muscle in man. Diabetologia 41:560-568

38. Divertie GD, Jensen MD, Miles JM (1991) Stimulation of lipolysis in humans by physiological hypercortisolemia. Diabetes 40:1228-1232

39. Djurhuus CB, Gravholy CH, Neilsen S et al (2002) Effects of cortisol on lipolysis and regional interstitial glycerol levels in humans. Am J Physiol Endocrinol Metab 283:E172-E177

40. Carlson MG, Snead WL, Campbell PJ (1993) Regulation of free fatty acid metabolism by glucagon. J Clin Endocrinol Metab 77:11-15

41. Green A, Dobias SB, Walters DJ, Brasier AR (1994) Tumor necrosis factor increases the rate of lipolysis in primary cultures of adipocytes without altering levels of hormone-sensitive lipase. Endocrinology 134:2581-2588

42. Souza SC, de Vargas LM, Yamamoto MT et al (1998) Overexpression of perilipin A and B blocks the ability of tumor necrosis factor alpha to increase lipolysis in 3T3-L1 adipocytes. J Biol Chem 273:24665-24669 